\title{
Education in the Area of Human Protection in Emergency and Crisis Situations in the Context of Health Education in the Czech Republic
}

Jitka Slaná Reissmannová ${ }^{1}$

$\approx$ The present time brings a number of emergency and crisis situations, including floods, fires or Covid-19, the management of which requires the active involvement of citizens. Lower secondary education in the Czech Republic includes the subject of Health Education, in which this topic is addressed. Education of students in the area of lifestyle and health is included in Health Education and Home Economics, the latter being delivered in Slovenia. In terms of content, both courses are similar and can enrich each other by sharing valuable experience both in teaching students and in preparing future elementary school teachers. The objective of this paper is to present the concept of elementary education in human protection in emergency and crisis situations in the Czech Republic and the related concept of undergraduate teacher training. The research methods used were document review (of curricular documents and study plans) and questionnaire survey. The paper presents the results of an analysis of the curricular document governing elementary education in the Czech Republic (Framework Education Programme for Elementary Education), as well as the results of an analysis of a health education textbook focusing on the area of safety issues. The paper also presents the results of an analysis of the study plans of selected faculties of education in terms of human protection in emergency and crisis situations, as well as the results of a questionnaire survey focusing on the awareness of future teachers in the area of human protection in emergency situations. The results and main findings of the analysis of the curricular document suggest that the topics of the human protection in emergency situations should be strengthened in the context of Health Education (and throughout elementary education). The studies on teachers' and future teachers' awareness of human protection in emergency situations (including first aid) point to some shortcomings in undergraduate teacher training (for example, the optional course in first aid and human protection in emergency situations at

1 Department of Physical and Health Education, Faculty of Education, Masaryk University, Czech Republic; jituler@post.cz. 
the Faculty of Education, Masaryk University). Conclusions and recommendations for practice: the current revision of the Framework Education Programme for Elementary Education should allow the strengthening of emergency issues in Health Education. Based on the inquiry, the following is recommended: due attention should be paid to all emergency issues in the course of education; further teacher training in all emergency issues should be promoted; emergency issues in undergraduate teacher training should be integrated in the form of compulsory common base courses.

Keywords: curriculum, health education, human protection in emergency situations, crisis management, teacher education 


\section{Izobraževanje na področju zaščite ljudi v izrednih in kriznih razmerah v okviru zdravstvene vzgoje na Češkem}

Jitka Slaná Reissmannová

$\propto$ Zdajšnji čas prinaša številne izredne in krizne razmere, vključno s poplavami, požari ali s covidom-19, katerih obvladovanje zahteva aktivno sodelovanje državljanov. Del osnovnošolskega izobraževanja na Češkem je tudi predmet zdravstvena vzgoja, pri katerem se obravnava navedena tema. Izobraževanje učencev na področju življenjskega sloga in zdravja je vključeno $\mathrm{v}$ zdravstveno vzgojo in gospodinjstvo, pri čemer se predmet pod tem imenom izvaja v Sloveniji. Vsebinsko sta si oba predmeta podobna in se lahko medsebojno povezujeta z izmenjavo dragocenih izkušenj pri poučevanju učencev in izobraževanju bodočih osnovnošolskih učiteljev. Namen tega prispevka je predstaviti koncept osnovnošolskega izobraževanja na področju varstva ljudi v izrednih in kriznih razmerah na Češkem in s tem povezan koncept dodiplomskega usposabljanja učiteljev. Uporabljeni raziskovalni metodi sta bili pregled dokumentov (kurikularnih dokumentov in študijskih načrtov) in anketni vprašalnik. V prispevku so predstavljeni rezultati analize kurikularnega dokumenta, ki ureja osnovnošolsko izobraževanje na Češkem (Okvirni izobraževalni program za osnovnošolsko izobraževanje), in rezultati analize učbenika zdravstvene vzgoje, ki se osredinja na področje varnostnih vprašanj. $\mathrm{V}$ prispevku so predstavljeni tudi rezultati analize študijskih načrtov izbranih pedagoških fakultet $\mathrm{z}$ vidika varstva ljudi $\mathrm{v}$ izrednih in kriznih razmerah ter rezultati anketnega vprašalnika, osredinjenega na ozaveščenost bodočih učiteljev na področju varstva ljudi v izrednih razmerah. Rezultati in glavne ugotovitve analize kurikularnega dokumenta kažejo, da bi bilo treba okrepiti temo zaščite ljudi v izrednih razmerah v okviru zdravstvene vzgoje (in v celotnem osnovnošolskem izobraževanju). Raziskave o ozaveščenosti učiteljev in bodočih učiteljev o temah zaščite ljudi v izrednih razmerah (vključno s prvo pomočjo) kažejo na nekatere pomanjkljivosti v dodiplomskem usposabljanju učiteljev (na primer izbirni predmet prve pomoči in zaščite ljudi v izrednih razmerah na Pedagoški fakulteti Masarykove univerze). Sklepi in priporočila za prakso: trenutne spremembe Okvirnega izobraževalnega 
programa za osnovnošolsko izobraževanje (v angl. Framework Education Programme for Elementary Education) bi morale omogočiti okrepitev tematike izrednih razmer pri zdravstveni vzgoji. Na podlagi raziskave se priporoča naslednje: $\mathrm{v}$ okviru izobraževanja je treba ustrezno pozornost nameniti vsem vprašanjem izrednih razmer; spodbujati je treba nadaljnje usposabljanje učiteljev za vsa vprašanja izrednih razmer; vprašanja izrednih razmer je treba vključiti v dodiplomsko usposabljanje učiteljev v obliki obveznih skupnih temeljnih predmetov.

Ključne besede: učni načrt, zdravstvena vzgoja, zaščita ljudi v izrednih razmerah, krizno upravljanje, izobraževanje učiteljev 


\section{Introduction}

The development of education in safety issues (human protection in normal as well as emergency situations, traffic education, civil preparation for the defence of the state, health training, crime prevention, the fight against terrorism and extremism) reflects the perception of safety threats within the Czech Republic and has a long tradition (Kovaříková \& Marádová, 2020).

In 1999, the Ministry of Education, Youth and Sports issued a directive to include the issue of human protection in emergency situations in education programmes. In this context, the Ministry of the Interior - Directorate General of Fire Rescue Service of the Czech Republic issued a resource for teachers containing information and recommendations for the education of human protection in emergency situations. In 2003, an amendment to existing learning resources entitled Human Protection in Emergency Situations was issued. The defence of the state is based on the Concept of Civil Preparation for the Defence of the State approved by the Czech government in 2013, which is reflected in the framework education programmes for elementary as well as secondary education. The preparation of citizens for the defence of the state focuses especially on medical preparation, preparation for civil protection, preparation for selfdefence, and mutual assistance in both military and non-military crisis situations. In 2018, the Ministry of Defence published a guide book entitled Civil Preparation for the Defence of the State - Guide for Elementary and Secondary School Teachers (Ministry of Defence, 2018).

The literacy (health/safety) of children (citizens of the Czech Republic) in the context of human protection in emergency situations (including first aid and prevention of infectious diseases) is defined by the Health Literacy Portal (2016), which determines the competences for each age category (children, young adults, adults and seniors).

Age group of children (7-15 years):

- In the area of Urgent First Aid and Safe Behaviour, the following competences are defined. The student: reports any health problems to an adult (family member, teacher, other well-known adult); calls for an adult in helpless situations; is able to treat a minor injury of him/herself or another person under adult supervision; knows the phone number 112 and is able to call it from a mobile phone; knows that s/he can help in serious situations; knows his/her name and surname (and the surname of his/her parents, if different); knows his/her address; is aware of the fact that dangerous situations may occur in the surrounding 
environment (at home, outside, in school); knows the basic principles of safe behaviour at home, in school and outside; and deliberately avoids dangerous locations.

A health-literate child of this age is capable of distinguishing between basic injury risk situations and is able to take appropriate action in health-threatening situations.

- In the area of Prevention of Infectious Diseases, the student: knows that some diseases are caused by micro-organisms (understanding that these are organisms invisible to the eye, "bad animals"); knows how a disease develops; knows the different ways of infection (spoiled food or drink, sneezing and coughing, insects and ticks, animal transmission, direct contact with a sick person); knows that people can get vaccinated against some diseases; and knows why vaccination is good (because it hurts much less than the disease that a person could get if not vaccinated) (Health Literacy Portal, 2016).

A prerequisite for high-quality teaching in schools is to have adequately trained teachers (Tilcerová, 2010). Teachers' and future teachers' literacy (health/safety) in relation to human protection in emergency situations (including first aid and prevention of infectious diseases) can also be defined with reference to the Health Literacy Portal according to the age groups "young adults" (students of the Faculty of Education, Masaryk University, beginner teachers) and "adults" (teachers).

- In the area of human protection in emergency situations (including first aid and the prevention of infectious diseases), the following health literacy areas are relevant to young adults (those related to the topic of the present paper).

- In the area of Urgent First Aid and Safe Behaviour, the young adult: is able to treat a minor injury of him/herself or another person and is able to determine in which cases professional assistance is needed; knows the contact details of his/her primary care physicians (general practitioner, dentist, gynaecologist) and other specialists, as well as the emergency medical service; if necessary, is able to call for professional assistance using emergency phone numbers and cooperates according to the instructions given by emergency specialists; in a health- or life-threatening situation, first strives to ensure the safety of him/herself and other unaffected persons; knows how to recognise life-threatening conditions; knows the typical symptoms of the most common serious diseases; is 
able to check the basic life functions of the affected person, perform cardiac massage and stop severe bleeding; knows the main principles of the general first aid procedure; understands the importance of safe behaviour for health; and recognises and is able to avoid situations with excessive risk to life and health.

A health-literate young adult understands the real risks of injury in everyday life as well as in extraordinary activities and behaves responsibly. Moreover, s/he is able to act appropriately in the case that his/her own health or the health of others is at risk.

- In the area of Prevention of Infectious Diseases, the young adult: informs an adult/parents or his/her physician in the case of a suspected infectious disease; knows which diseases are vaccinated against as part of regular vaccination; knows which diseases $s /$ he is vaccinated against and knows where his/her vaccination card is; knows that infectious diseases are not of the same risk in all territories; and knows that before travelling abroad or before an exceptional event a physician should be consulted regarding prevention possibilities.

- In the area of human protection in emergency situations (including first aid and the prevention of infectious diseases), the following health literacy areas are relevant to adults (those that are related to the topic of the present paper).

- In the area of Urgent First Aid and Safe Behaviour, the adult: is able to treat a minor injury of him/herself or another person and is able to determine in which cases professional assistance is needed; knows the contact details of his/her primary care physicians (registered general practitioner, dentist, gynaecologist) and other specialists; knows the contact details of the doctors of the persons in his/her care as well as the emergency medical service; if necessary, is able to call for professional assistance using emergency phone numbers; knows how to cooperate according to the instructions given by emergency specialists; in a health- or life-threatening situation, first strives to ensure the safety of $\mathrm{him} /$ herself and other unaffected persons; knows how to recognise life-threatening conditions; knows the typical symptoms of the most common serious diseases; is aware of the fact that in the case of old people, the symptoms of serious diseases may be difficult to recognise; knows the basic principles of general first aid and is able to check the basic life functions of the affected person, perform cardiac massage and stop 
severe bleeding; in the context of childcare, knows what to do in the case of fever, fever convulsions, severe vomiting and diarrhoea; understands the importance of safe behaviour in order to protect his/her health and the health of people in his/her care; knows how to recognise and is able to avoid situations with excessive risk to life and health; is able to explain these principles to his/her children or people in his/her care; and is able to determine which risk situations a person is able to resolve him/herself and when direct supervision is necessary.

A health-literate adult understands the real risks of injury in everyday life as well as in extraordinary activities and behaves responsibly. Moreover, s/ he brings up his/her children or other persons in his/her care in this sense and is able to act accordingly in the case that his/her own health or the health of others is at risk.

- In the area of Prevention of Infectious Diseases, the adult: is aware of the danger of infectious diseases not only for him/herself, but also for other people in terms of the spreading of the infection in the family, in the workplace or in a group of people who are in contact, and is able to act accordingly; is aware of the danger of sexually transmitted diseases and knows how to behave and protect him/herself; assumes responsibility for explaining the basic hygiene habits and anti-infection measures to his/her children; has his/her children regularly vaccinated in compliance with the legal vaccination calendar and is able to decide responsibly on vaccinations recommended by physicians to him/herself or his/her children or people close to him/her (cocoon strategy) (Health Literacy Portal, 2016).

Safety literacy and teacher competences are further defined by Kovaříková and Marádová (2020), according to whom safety literacy is "a set of knowledge, skills and attitudes that allows safe movement in today's society". In relation to the teaching profession, it is "a set of knowledge, skills and ways of thinking required for safe movement in today's society and the competence to prevent and cope with crisis situations in a school setting". A prerequisite is the teacher's ability to effectively respond to normal risks and emergency situations related to the teaching profession and, in the case of an emergency, protect him/ herself and his/her pupils (Kovaříková \& Marádová, 2020, pp. 37-38).

Kovaříková (2018, p. 54) presented a modified integrated model of teaching Health and Risk/Safety Education (see Figure 1 below) of the European 
Agency for Safety and Health at Work (OSHA, 2021), which reflects the health promotion and safety strategy in schools. In the long term, the agency has promoted the concept of a "risk prevention culture", a term that is based on the concepts of "safety culture" and "health culture". Increasing the level of safety and health literacy is becoming a natural part of lifelong learning (Kovaříková, 2018, p. 54; Kovař́íková, Marádová, 2020, p. 47; OSHA, 2010).

\section{Figure 1}

Integrated model of teaching Health and Risk/Safety Education

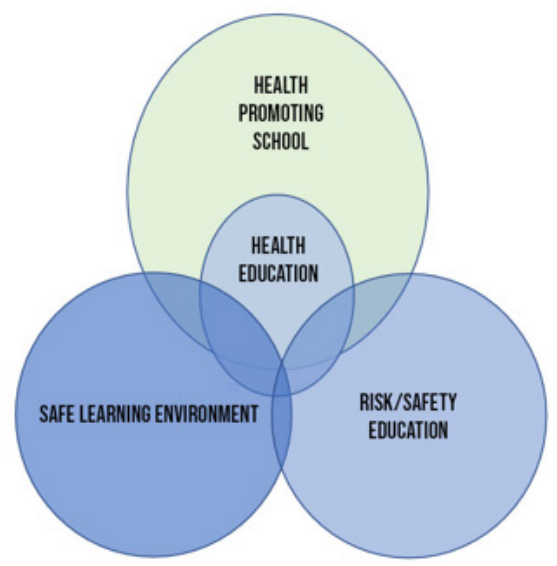

Note. Adapted from Kovaříková, 2018.

The model shows how the themes in the formal curriculum (e.g., in Health Education) overlap and complement each, and how they are linked to the life of every school and pupils' personal experience.

It should not be forgotten that the issue of safety and a safe environment is not entirely new in schools. The World Health Organization is the co-author (together with the Council of Europe and the European Union) of the European Network of Health Promoting Schools (Havlínová et al., 1998, Nejedlá et al., 2015; SHE, 2021). In the Czech Republic, the health promotion programme has been in place in schools since 1992 (Reissmannová, 2005). As of 31 May 2020, the network of health-promoting schools included a total of 355 nursery, elementary and secondary schools.

A more recent programme focusing on the promotion of a safe environment in Czech schools and on crises situations is the Safe School programme (Safe School, 2016). The Safe School programme promotes activities that lead to a reduction in injuries and violence in schools and support children's and 
young people's preventive behaviour, which they adopt for life. A school that wishes to join the network of schools involved in the programme must work with seven indicators and seven categories (Pokorná, Indicators and Criteria, 2009).

The Safe School programme is not very known in the Czech Republic; according to the Safe School website, only nine schools are involved.

The issue of safety in schools is also addressed by the European Commission in a document entitled Communication from the Commission to the European Parliament and the Council on Education in Emergencies and Protracted Crises (2018), which requires schools to ensure a safe, protected and high-quality learning environment. At the same time, the Communication emphasises the importance of teacher education and requires the promotion and implementation of the principles and guidelines of Conflict Sensitive Education - such as ensuring that teaching fosters respect for diversity, tolerance and active responsible citizenship - through teacher training, curriculum development and professional development of teachers (EU, 2018).

The Czech School Inspectorate recommends that further teacher training should be supported in all safety issues, and that safety issues should be included in undergraduate teacher training (Czech School Inspectorate, 2016).

This finding was presented by the Czech School Inspectorate in 2016, although the Government of the Czech Republic had already approved the inclusion of Human Protection in Emergency Situations, Healthcare and Traffic Education in undergraduate study programmes in 2011 by means of Resolution No. 734. The following three-level system of study domains was developed to be implemented in university programmes for future teachers:

- $\quad$ Study Domain I - intended for all future teachers across disciplines as a specific basis of knowledge (elementary skills and knowledge concerning the prevention of emergency situations and the protection of oneself and pupils in the event of emergency situations);

- $\quad$ Study Domain II - intended for students of Health Education (deeper knowledge and skills including the ability to pass on the acquired information to others);

- $\quad$ Study Domain III - intended for students of single- and double-major study programmes aimed at civil protection combined with another subject (deeper knowledge and skills including the ability to pass on the acquired information acquired to others) (Integration of Human Protection in Emergency Situations, Health Protection and Traffic Education, Fire Rescue Service of the Czech Republic, pp. 2-3). 
The Study Domains were designed in 2011; in 2017, the Government of the Czech Republic approved the Concept of Education in Civil Protection and Crisis Management, which replaced the previous concept of 2004. The new concept defines the target groups that should be primarily addressed in the process of education, including academic staff who prepare future teachers (students of faculties of education), as well as teachers in nursery, elementary, secondary and higher vocational schools who teach safety issues (Education in the Area of Civil Protection and Crisis Management, 2017).

For the target group of teachers, Module J - Civil Protection and Crisis Management for Teachers was issued in 2019. The module covers the theory of human protection in emergency situations (Ministry of the Interior - Directorate General of Fire Rescue Service of the Czech Republic, 2019).

\section{Method}

In 2021, three research sub-studies were conducted with the aim of answering the following research questions:

1. How is the issue of education related to human protection in emergency situations implemented in the curricular documents for elementary education?

2. How is the issue of education related to human protection in emergency situations implemented in the curricular documents for undergraduate preparation of future teachers in selected faculties of education?

3. What is the degree of awareness of bachelor's students in the first years at the Faculty of Education, Masaryk University and the Faculty of Education, Palacký University in the area of human protection in emergency and crisis situations?

Document review. The following curricular documents for elementary education were analysed: Framework Education Programme for Elementary Education 2021 and publicly accessible study plans of the five faculties of education. The review of documents was performed in January (Slaná Reissmannová, 2021). Keywords: occupational safety and human protection in emergency situations, first aid, civil defence education, risk education, safety education.

Questionnaire survey. The purpose of the questionnaire survey was to investigate the degree of awareness about human protection in emergency situations. The data were obtained by means of a questionnaire survey carried out using Google technology. The data were converted into MS Excel (Slaná Reissmannová, 2021). 
The research sample comprised 233 students of the Faculty of Education, Masaryk University (210 respondents/90\%) and the Faculty of Education, Palacký University (23 respondents/10\%). The following students of bachelor's degree programmes were involved: 197 respondents $(84.5 \%)$ in year one of a double-major bachelor's degree (41 students of Health Education) and year one of the bachelor's degree Teacher Training for Nursery Schools, and 36 respondents $(15.5 \%)$ in year one of the five-year master's degree Teacher Training for Primary Schools. Gender groups: 39 male (17\%), 194 female (83\%). Age groups: 19-51 years, the largest group was 19 years of age (44\%).

The research part of the project was carried out between 5 October 2020 and 17 January 2021.

The first set of questions asked about the respondents' opinions about teaching the issue of human protection in emergency situations in the context of undergraduate teacher training.

The second set of questions evaluated the cognitive dimension and comprised 35 test items. Evaluation of the knowledge part of the questionnaire: cut-off score of $80 \%$. The cut-off score of $80 \%$ is based on the traditional assessment algorithm used in the system of education (Hřivnová, 2018). A total of 27 questionnaire items were adopted from test questions intended for grade nine of elementary school (Teaching Resources, 2004).

\section{Results}

\section{The implementation of the issue of human protection in emergency and crisis situations in elementary education: Analysis of the Framework Education Programme for Elementary Education and publicly accessible resources for elementary school teachers}

The outcomes defined in the Framework Education Programme for Elementary Education (2021) in the educational area Man and Health and the educational field Health Education relating to human protection in emergency and crisis situations are as follows: respects the accepted rules for coexistence among peers and partners and contributes to the formation of good interpersonal relations in the community; assesses various ways of human behaviour in terms of responsibility for one's own health and the health of others and assumes personal responsibility in favour of active health promotion; endeavours within his/her abilities and experience to actively support health; manifests responsible behaviour in risk situations of road and railway transport; actively 
prevents endangerment of health and personal safety; provides adequate first aid if necessary; applies adequate behaviour and protection in model risk situations, danger and emergency situations (Framework Education Programme for Elementary Education, 2021, pp. 99-100).

Each of the Framework Education Programmes for Elementary Education (FEP EE) issued so far $(2005,2013,2017,2021)$ mentions the issue of safety in Chapter 10, entitled Material, Personal, Sanitary, Organisational and Other Conditions for Implementing the FEP EE (e.g., FEP EE 2021): conditions for hygienic and safe education: life of the school, protection of pupils against injury, availability of first-aid resources, contact details of physicians or a different medical service, practical capacity of the teachers to provide first aid (FEP EE, 2021); organisational conditions: an optimal school regimen in accordance with safety standards (hygiene, emergency situation) (FEP EE, 2021); psychosocial conditions: education reasonably linked to everyday life; favourable social climate, strengthening mutual respect, [...] empathy, cooperation and mutual help, solidarity with one's class and school; protection of pupils against violence, bullying and other antisocial phenomena; pupils' participation in education and activities of the school based on the model of a democratic community, building a community on the principles of freedom, responsibility, stability of common rules, justice and cooperation; timely provision of information concerning the different issues in school and outside school (FEP EE 21, 2021).

According to an analysis of the available resources for elementary school teachers, there is an abundance of resources that are clearly arranged on the website of the Fire Rescue Service of the Czech Republic: "Resources and Textbooks" (FRS CR, n.d.).

Most of the resources/textbooks date back to 2002-2006, which makes them slightly outdated and not responding to the needs and threats of current society and the world.

In the context of Health Education, which is an area that focuses mainly on the issue of human protection, only one textbook approved by the Ministry of Education, Youth and Sports is used: KREJČÍ et al. Výchova ke zdravému životnímu stylu: pro 2. stupeň ZŠ a odpovídající ročníky víceletých gymnázií, published by Fraus in 2018. In this textbook, the issue of human protection in emergency situations is addressed in Chapter 7 Human Protection in Emergency Situations on a total of seven pages (pp. 183-190). The chapter contains the following: Emergency Situation (p. 184), Integrated Rescue System (pp. 185-186), Civil Protection Service (pp. 187-188), Armed Forces of the Czech Republic (p. 189), and Revision of Lesson 7 (p. 190). The textbook does not focus in detail on the issue of first aid, which is also part of human protection in 
emergency situations (half a page on p. 188).

The problematic aspect is the didactic transformation of the issue in order to be handled easily by elementary school teachers, including both qualified health education teachers, who should be more knowledgeable about the issue according to Study Domain II, and unqualified teachers. According to a survey carried out by the Czech School Inspectorate (2016), teachers would appreciate additional methodological resources, teaching aids and a broader offer of teacher training courses aimed at this issue (Teaching of Safety Issues, 2016).

It is important to mention that the current Covid-19 pandemic is identified according to the International Health Regulations as a biological threat.

Both the Resources document and the health education textbook fail to mention the issue of biological threats or infectious diseases.

\section{Implementation of human protection in emergency and crisis situations in undergraduate teacher training: Analysis of the study plans of selected faculties of education that deliver the study programme Health Education - bachelor's and follow-up master's degree programmes}

Regarding the concept of Study Domain I (common base courses for all students of faculties of education) and Study Domain II (for students of Health Education), the analysis of the study plans included those faculties of education that train future teachers of Health Education. This applies to the following faculties of education: Faculty of Education, Palacký University Olomouc; Faculty of Education, Masaryk University in Brno; Faculty of Education, University of West Bohemia in Pilsen; Faculty of Education, Charles University in Prague; Faculty of Education, University of Ostrava.

The analysis included the study plans (bachelor's and follow-up master's degree programmes) published on the faculties' websites.

The following study plans were analysed: 1) common base courses, 2) Health Education programme - bachelor's and master's degree programmes.

\section{Faculty of Education, Masaryk University in Brno}

The common base courses do not include a compulsory course concerning the issue of human protection in emergency situations. As a result, there is no compulsory or core elective course in the common base courses in the bachelor's or master's degree programmes focusing on the issue of human protection in emergency situations or first aid. Regarding the teachers' work, this situation is highly alarming. As far as optional courses are concerned, it is 
possible to enrol in Occupational Safety and Human Protection in Emergency Situations, and First Aid with Elements of Experiential Education.

The bachelor's degree programme Health Education includes a compulsory course Human Protection in Emergency Situations. In terms of content, this course does not fulfil the requirements of Study Domain II or Module J. First aid is taught as a compulsory course. The master's degree programme Health Education does not include a course concerning the issue of human protection in emergency situations. First aid is included in the compulsory course First Aid in the School Setting (Faculty of Education Brno, 2021).

\section{Faculty of Education, Palacký University Olomouc}

There is no compulsory or core elective course in the common base courses in the bachelor's or master's degree programmes focusing on the issue of human protection in emergency situations or first aid. The bachelor's degree programme Health Education includes the compulsory course Civil Protection in Emergency Situations and First Aid in year two. The master's degree programme Health Education does not include a course focusing on human protection in emergency situations or first aid, but includes Hygiene and Epidemiology, which covers the topic of infectious diseases in the context of epidemics, pandemics and the vaccination system in the Czech Republic.

The Department of Adapted Physical Activities of the Faculty of Physical Culture offers the bachelor's degree programme Physical Education, with a focus on teaching and civil protection, and the follow-up master's programme Teacher Training in Physical Education for Lower Secondary Schools and Secondary Schools and Civil Protection (Faculty of Education Olomouc, 2021).

\section{Faculty of Education, University of West Bohemia in Pilsen}

The university's website does not provide the required information, but according to the university, the common base courses do not include human protection in emergency situations. The bachelor's degree programme Health Education includes the compulsory course Fundamentals of First Aid and Crisis Intervention in year two. The bachelor's degree programme does not include a course focusing on human protection in emergency situations. The Crisis Intervention course includes the following topics: a description of concepts relating to crisis intervention, crisis and crisis situations, emergencies and emergency situations. The master's degree programme Health Education includes Human Protection in Emergency Situations, but the content of the course does not fulfil the requirements of Study Domain II or Module J. Currently, an optional course Civil Defence Education and Survival in Nature is being prepared. 
It should be noted that the Faculty of Education in Pilsen provides training of health education teachers and focuses on interactive psychosocial training and personality-social development (Svoboda, 2017; Svoboda \& Gažáková, 2020), which is essential for emergency and crisis management (Faculty of Education Pilsen, 2021).

\section{Faculty of Education, Charles University in Prague}

The common base courses of the bachelor's and master's degree programmes do not include a compulsory or core elective course focusing on human protection in emergency situations or first aid. The bachelor's degree programme Health Education includes a compulsory course Protection in Emergency Situations in year two and the core elective course First Aid in year three. The master's degree programme Health Education does not include a course focusing on human protection in emergency situations, but there is a compulsory subject Prevention of Health Risks (topics: population health, risk factors influencing health; the effects of physical, chemical and biological factors on health; safety and health protection at work). In compulsory elective courses we find the topics: security issues in schools; and preparing citizens for state protection (Faculty of Education Prague, 2021).

\section{Faculty of Education, University of Ostrava}

There is no compulsory or core elective course in the common base courses in the bachelor's or master's degree programmes focusing on the issue of human protection in emergency situations or first aid. The bachelor's degree programme Health Education does not include a course focusing on human protection in emergency situations. There is the compulsory course Fundamentals of Hygiene and Epidemiology, which covers the following topics: spreading of infectious diseases, vaccination against infectious diseases, epidemiology of selected infectious diseases. The master's degree programme Health Education does not include a course focusing on human protection in emergency situations or first aid (Faculty of Education Ostrava, 2021).

The analysis of the study plans of selected faculties of education revealed the alarming finding that the study plans of the common base courses of the bachelor's and master's degree programmes of all the faculties of education included in the study did not have a compulsory or core elective course focusing on human protection in emergency situations pursuant to Study Domain I. As suggested by the analysis of the study plans of Health Education, none of the faculties meets the requirement of Study Domain II. 


\section{Awareness of future teachers: Questionnaire survey to identify the level of awareness among teacher training students in the area of human protection in emergency situations}

Results of the questionnaire survey:

- $\quad$ As many as $97 \%$ of the respondents believe that the issue of human protection in emergency situations is important for future teachers, while $72 \%$ reported that it should be part of compulsory courses in undergraduate teacher training, and $85 \%$ believe that first aid should be compulsory in undergraduate teacher training.

- Concerning the level of awareness about human protection in emergency situations, $17 \%$ of the respondents did not achieve the required threshold of $80 \%$ of correct answers. The maximum number of points was 34 ( $80 \%$ equals 27 correct answers). The average number of points achieved was 27 , the mode was 29 . The lowest number of points (19) was achieved by only one respondent, while the maximum number of points (34) was also achieved by one respondent.

\section{Questions for which the threshold of $80 \%$ of correct answers was not} achieved:

- Desirable behaviour in the event of an earthquake (answered correctly by $39 \%$ of the respondents).

- Infectious diseases used for bioterrorism (answered correctly by $41 \%$ of the respondents).

- Desirable behaviour in the event of an accident involving the escape of a hazardous substance (answered correctly by $44 \%$ of the respondents).

- An epidemic cannot be described by a specific number (answered correctly only by $50 \%$ of the respondents).

- Desirable behaviour in the event of an avalanche (answered correctly by $59 \%$ of the respondents).

- $\quad$ Correct first aid procedure and use of an autotransfusion position (answered correctly by $61 \%$ of the respondents).

\section{The main results of the survey are listed below.}

The resources for elementary education do not include the area of biological threats (such as Covid-19) or, to be more specific, infectious diseases. The topic of human protection in emergency situations is not suitably transformed from a didactic perspective.

The analysis of the study plans of selected faculties of education revealed 
the alarming finding that the study plans of the common base courses of the bachelor's and master's degree programmes did not have a compulsory or core elective course focusing on human protection in emergency situations pursuant to Study Domain I. As suggested by the analysis of the study plans of Health Education, none of the faculties meets the requirement of Study Domain II.

The students' awareness can be rated as sufficient (the required success rate of $80 \%$ was not achieved by $17 \%$ of the students).

\section{Discussion}

The results of partial studies often emphasise the insufficient inclusion of the issue of human protection in emergency situations in the curriculum of elementary and secondary education, as well as an inadequate level of health literacy of the citizens of the Czech Republic (Holčík, 2017; Kučera et al., 2016).

In 2009, the Ministry of the Interior - Directorate General of Fire Rescue Service of the Czech Republic performed a quick inquiry in 2,725 elementary and secondary schools and observed that human protection in emergency situations was covered by more than half of the schools involved in the survey. According to a thematic report (2016) of the Czech School Inspectorate entitled Education in Safety Issues, 91\% of elementary schools (the total number of elementary schools was 107) addressed the issue of human protection against normal risks and emergency situations, while civil preparation for the defence of the state was included by significantly fewer schools (63.1\%).

For all safety issues (traffic education, civil preparation for the defence of the state, human protection against normal risks and in emergency situations, health protection), the content is usually included in different subjects (most of the teachers in the schools included in the survey are comfortable with this situation). Teacher qualification concerning safety issues mostly corresponds with the subjects in which these issues are included. The methods and forms used in teaching safety issues are dominated by practical exercises, drills, project days, discussions and teacher presentations. In terms of educational events and practical exercises, the most frequent were first-aid drills, evacuation drills, traffic competitions and exercises in the event of a fire or flood.

In 2016/2017, the Czech School Inspectorate tested 6,174 pupils from grade nine of elementary schools (Selective Testing of Pupils' Performance in Grade Five and Nine of Elementary Schools, 2017). The test designed for pupils from grade nine focused on protection in risk situations and consisted of 35 tasks, some of which were further divided into sub-items.

In total, 63 test items were evaluated. The items of the test focusing on 
protection in risk situations designed for pupils from grade nine included the following five thematic areas: (a) Road Traffic (15 test items), (b) Health Protection (8 test items), (c) Emergency Situations (11 test items), (d) Defence of the State (13 test items), and (e) Crime Prevention (16 test items).

The pupils' average achievement in Health Protection was 54.3\%, Emergency Situations 53.3\% and Defence of the State 50.5\%. The worst achievement in the entire test was observed in the following items: Basic Safety Evacuation Procedures (3\%) and Evacuation Pack Content (8\%). The proportion of correct answers was below $10 \%$.

In 2014, Hřivnová conducted a research study among pupils from grade nine of elementary schools, whose task was to subjectively identify the themes that are preferred, dominant and absent in Health Education. In the study, a total of ten absent themes were identified, among which human protection in emergency situations was seventh (Hřivnová, 2018).

Marádová (2007) conducted a questionnaire survey among the students of the Faculty of Education, Charles University in Prague, focusing on their knowledge of the issue of human protection in emergency situations. According to Marádová, the survey revealed significant shortcomings in the level of education among secondary school graduates (teacher training students) concerning the issue of human protection in emergency situations. The key approach to improve this condition is increasing the quality of teacher training in this area. This requires conceptual curricular changes of undergraduate teacher training in all relevant study programmes (Marádová, 2007). These conceptual changes were made in 2011, but similar studies do not bring satisfactory results.

A similar study was conducted in 2010 on the awareness of students of the Faculty of Education, Masaryk University in the area of first aid (first aid is also included in human protection in emergency situations). According to the results, the awareness of students concerning the issue of first aid is insufficient and it is desirable to strengthen the teaching of first aid in all study programmes (Prokopová \& Reissmannová, 2008; Reissmannová, 2010).

Tilcerová (2010) states that the most important problems in teaching human protection in emergency situations in elementary schools include the insufficient number of qualified teachers, fragmentation of the teaching process, as well as insufficient control and feedback.

In her survey aimed at teacher training at the Faculty of Education, Masaryk University, Jašková (2020) observed that the interest of students in Occupational Safety and Human Protection in Emergency Situations had dropped dramatically. The author further observed that only $10.2 \%$ of the students (of a total of 68 respondents) in the survey believed that they were sufficiently 
provided with practical skills in delivering first aid, while $86.4 \%$ of the respondents believed that it would be desirable to include a compulsory first aid course, as $79.7 \%$ (47) of the students had not taken a first aid course and would appreciate its introduction. Only $42.4 \%$ of the students responded adequately to the test items. From 2011 to 2015, first aid was included in the compulsory common base courses taught in the first grade. However, after the conceptual changes made to the common base courses, the Faculty of Education, Masaryk University has not had a compulsory course that includes first aid, healthcare or human protection in emergency situations.

In the 2016 survey carried out by the Czech School Inspectorate on education in safety issues, the focus was also on how (and whether at all) teachers had been trained during their undergraduate study in the areas of traffic education, human protection, health protection and civil preparation for the defence of the state, and whether schools believed that these issues should be part of teacher training courses.

\section{Conclusions}

Based on the analysis of the Framework Education Programme for Elementary Education (2021) and the study plans of selected faculties of education in the Czech Republic, the authors conclude that the issue of human protection is not sufficiently included in elementary education or undergraduate teacher training.

The current Covid-19 pandemic should lead to a cross-sectoral debate, revision and implementation of relevant issues, as well as the strengthening of the role of Health Education. A precondition is the definition of the terms health literacy/competence and safety literacy/competence in the curriculum of elementary education and in undergraduate training of future teachers - the teachers of the future generation.

For this reason, the authors have proposed a number of measures that could help strengthen the delivery of human protection in emergency situations at the Faculty of Education, Masaryk University in Brno, as well as other faculties. The authors have also proposed recommendations for educational practice in elementary schools and recommendations for a revision of the documents issued by the Ministry of the Interior - Directorate General of Fire Rescue Service of the Czech Republic. 


\section{Recommendations for educational practice in elementary schools}

- Strengthening the delivery of human protection in emergency situations using suitable methods (especially simulation) throughout the whole period of compulsory education, and development of appropriate methodological resources for teachers of all qualifications.

- $\quad$ Strengthening the delivery of human protection in emergency situations in Health Education: development of appropriate methodological resources for health education teachers and of a new health education textbook.

- Implementation of the issue of infectious diseases and their prevention in Natural History and Health Education (general prevention recommendations, hand washing, awareness-raising of the importance of vaccination).

- In the revision of the Framework Education Programme for Elementary Education 2023, the following terms should be included: health literacy/ health competence and safety literacy/safety competence.

- The issue of human protection in emergency situations should be included in all educational areas of the Framework Education Programme for Elementary Education.

\section{Recommendations for educational practice in faculties of education}

- Implementation of a compulsory course concerning the issue of human protection in emergency situations in the common base courses of all study programmes according to Study Domain I and Module J.

- Implementation of a compulsory course concerning the issue of human protection in emergency situations in the study programme Health Education pursuant to Study Domain II and Module J in full extent.

- Implementation of compulsory first aid in the common base courses.

- Strengthening cooperation with experts from practice (Integrated Rescue System).

- Development of thematic e-learning courses.

- Discussion of the results with representatives of other faculties of education and proposals for adequate measures in expert fora.

- Development of methodological resources for students and teachers in cooperation with experts from practice and elementary schools.

- $\quad$ Further research studies focusing on the educational reality at all school levels.

At present, experts from the Faculty of Education, Masaryk University are working on three methodological resources (team of authors: Mertová et 
al., 2021) that will cover the entire area of human protection in emergency situations as defined by the materials of the Fire Rescue Service of the Czech Republic. Each of them will comprise ten lessons including theoretical training of teachers and didactic transformation of the learning content, as well as structured preparation and worksheets with a key. The methodological resource prepared by Mertová and Slaná Reissmannová is included in the 2021 publishing schedule of the Ministry of the Interior - Directorate General of Fire Rescue Service of the Czech Republic.

The European region is facing new threats and is still exposed to a considerable human health hazard. Fatal events such as the current Covid-19 pandemic, the severe acute respiratory syndrome (SARS) epidemic in 2003, the $\mathrm{H}_{1} \mathrm{~N}_{1}$ global pandemic in 2009, natural disasters, war conflicts, climate changes with extreme weather fluctuations, urbanisation, and the development of international airports and mass gatherings are all the risks and threats of modern times that must be actively reflected in the education of the new generation to ensure that they are better prepared for these events. These events and situations must be taken seriously and should be given the importance that they deserve in the context of education.

\section{References}

Brzybohatá, A., \& Mráčková, K. (2019). Ve školách chybí branná výchova. Děti umí telefonní čísla, ve zbytku tápou [Schools lack military education. Children know phone numbers, the rest are groping]. https://www.idnes.cz/zpravy/domaci/hasici-zachranari-policie-povodne-pozary-nehody-deti-ucenibranna-vychova.A190416_164959_domaci_brzy

Czech School Inspectorate. (2016). Tematická zpráva Vzdélávání v bezpečnostních tématech [Thematic report: Education in security topics]. https://www.csicr.cz/Csicr/media/Prilohy/PDF_el._publikace/ Tematick\%c3\%a9\%2Ozpr\%c3\%a1vy/2016_TZ_vzdelavani_v_bezpecnostnich_tematech.pdf Czech School Inspectorate. (2017). Výběrové zjištování výsledkủ žáků na úrovni 5. a 9. ročníků základních škol ve školním roce 2016/2017 - závěrečná zpráva [Sample survey of students' results at the level of the fifth and ninth grades of primary school in the 2016/2017 school year - final report]. https://www.csicr.cz/getattachment/17f8e265-bo4f-4459-a106-3aecbf735cao/Vyberove-zjistovanivysledku-zaku-na-urovni-5-a-9-rocniku-ZS-zaverecna-zprava.pdf

European Union. (2018). Sdělení komise Evropskému parlamentu a Radě o vzdělávání v mimořádných situacich a vleklých krizich [Communication from the Commission to the European Parliament and the Council on emergency and protracted education]. https://eur-lex.europa.eu/legal-content/CS/AL $\mathrm{L} /$ ?uri=COM\%3A2018\%3A0304\%3AFIN Faculty of Education, Masaryk University. (2021). Studijní katalog [Study catalogue]. https://www. ped.muni.cz/student/bc-a-mgr-studium/studijni-katalog 
Faculty of Education, Palacký University Olomouc. (2021). Studijní agenda UPOL [Study catalogue Palacký University Olomouc]. https://stag.upol.cz/portal/

Faculty of Education Ostrava. (2021). Nabizené programy a obory [Offered programmes and fields]. https://pdf.osu.cz/kpe/nabizene-programy-a-obory/

Faculty of Education Pilsen. (2021). Studijní agenda [Study catalogue]. https://portal.zcu.cz/portal/ Faculty of Education Prague. (2021). Studijní plány - Karolínka [Study plans - Karolínka]. https:// pedf.cuni.cz/PEDF-2171.html

Fire Rescue Service of the Czech Republic. (2021). Výuka problematiky ochrany člověka za běžných rizik a mimořádných událostí na školách - od historie $k$ současnému stavu [Teaching the issue of human protection under common risks and emergencies in schools - from history to the current state]. https://www.hzscr.cz/clanek/vychova-a-vzdelavani-obyvatelstva-vychovaa-vzdelavani-obyvatelstva-podpora-vyuky-ze-strany-hasicskeho-zachranneho-sboru-cr. aspx?q=Y2hudWo9NA\%3D\%3

Fire Rescue Service of the Czech Republic. (2004). Podklady a učebnice [Materials and textbooks]. https://www.hzscr.cz/clanek/podklady-a-ucebnice.aspx

Framework Education Programme for Elementary Education (FEP EE) (2021) Rámcový vzdělávací program pro základní vzdělávání. http://www.nuv.cz/t/rvp-pro-zakladni-vzdelavani Government of the Czech Republic. (2011). Usnesení č. 734. Začlenění tématik Ochrana člověka za mimořádných událostí, péče o zdraví a dopravní výchova do studijních programů pedagogických fakult [Resolution No. 734. Incorporation of the topics of Human Protection in Emergencies, Health Care and Traffic Education into the study programmes of pedagogical faculties]. https://www.hzscr.cz/ clanek/material-zacleneni-tematik-ochrana-cloveka-za-mimoradnych-udalosti-pece-o-zdravi-adopravni-vychova-do-studijnich-programu-pedagogickych-fakult.aspx

Government of the Czech Republic. (2017). Koncepce vzdělávání v oblasti ochrany obyvatelstva a krizového řízení [Education in the Area of Civil Protection and Crisis Management]. https://www. hzscr.cz/clanek/vzdelavani-v-oblasti-ochrany-obyvatelstva-a-krizoveho-rizeni.aspx Havlínová, M., \& Vildová, Z. (2005). Úvod. Průvodce výchovou ke zdraví. Učitelské listy. Příloha Ratolesti podpory zdraví ve školách [Introduction. Guide to health education. Teacher's sheets. Annex Branches of health promotion in schools]. http://www.ceskaskola.cz/2001/og/bibliografieucitelskych-listu-19932008.html

Health Literacy Portal. (2016). Zdravotní gramotnost. http://zdravotnigramotnost.cz/ Holčík, J. (2017). Zdravotní gramotnost a zdravotní politika [Health literacy and health policy]. http:// www.uzg.cz/doc/Kolokvium_Sbornik.pdf

Hřivnová, M. (2018). Analýza a evaluace kurikula vzdělávacího oboru Výchova ke zdraví [Analysis and evaluation of the curriculum of the educational field of health education]. Jašková, M. (2020). Sonda do znalostí laické první pomoci u studentů Pedagogické fakulty Masarykovy university [A probe into the knowledge of lay first aid for students of the Faculty of Education at Masaryk University]. https://is.muni.cz/th/ffkw1/

Kovaříková, M., \& Marádová, E. (2020). Didaktika výchovy ke zdraví a bezpečí v kontextu kurikulární 
a učitelského vzdělávání [Didactics of health and safety education in the context of curricular reform and teacher education]. Pedagogická fakulta UK Praha.

Kovař́ḱvová, M. (2018). European tendencies in education in the field of health and safety [online]. In B. Hošková \& J. Slaná Reissmannová (Eds.), Život ve zdraví 2018: teorie a praxe (pp. 53-56). https:// munispace.muni.cz/library/catalog/view/1146/3320/834-1/o\#preview

Krejčí, M., Šulová, L., Rozum, \& F. Havlíková, D. M. (2018). Výchova ke zdravému životnímu stylu: pro 2. stupeň ZŠ a odpovídající ročníky víceletých gymnázií [Education for a healthy lifestyle: For the second grade of primary school and the corresponding years of multi-year grammar schools]. Fraus. Marádová, E. (2007). Pilotní studie prípravy budoucích učitelů v oblasti ochrany člověka za mimoŕádných událostí [Pilot study on the training of future teachers in the field of human emergency protection]. https://www.hzscr.cz/clanek/pilotni-projekt-priprava-budoucich-ucitelu-v-oblastiochrany-cloveka-za-mimoradnych-udalosti.aspx

Kučera, Z., Pelikan, J., \& Šteflová, A. (2006). Zdravotní gramotnost obyvatel ČR-výsledky komparativního reprezentativního šetření [Health literacy of the population of the Czech Republic results of a comparative representative survey]. Časopis lékařro českých č, 5/2016/155, 233-241. https:// www.prelekara.sk/casopisy/casopis-lekaru-ceskych/2016-5/zdravotni-gramotnost-obyvatel-crvysledky-komparativniho-reprezentativniho-setreni-59024

Mertová, M., Lízalová, V., \& Slaná Reissmannová, J. (2021). Soubor metodických materiáli̊ k výuce ochrany člověka za mimořádných událostí [A set of methodological materials for teaching human protection in emergencies]. Masaryk University Brno.

Ministry of Defence of the Czech Republic. (2018). Př́prava občanů k obraně státu [Preparing citizens to defend the state]. http://www.pokos.army.cz/pro-skoly-ucitele Ministry of the Interior - Directorate General of Fire Rescue Service of the Czech Republic. (2013). Koncepce ochrany obyvatelstva do roku 2020 s výhledem do roku 2030 [The concept of population protection until 2020 with a view to 2030 ]. https://www.hzscr.cz/clanek/ochrana-obyvatelstva-vceske-republice.aspx

Ministry of the Interior - Directorate General of Fire Rescue Service of the Czech Republic. (2019). Modul J Ochrana obyvatelstva a krizové rízení pro pedagogické pracovníky [Module J Population protection and crisis management for teachers]. https://www.hzscr.cz/clanek/moduly-dle-platnekoncepce-vzdelavani-v-oblasti-ochrany-obyvatelstva-a-krizoveho-rizeni-2017.aspx Nejedlá, M. et al. (2015). Program škola podporující zdraví [Health promoting school program]. http://www.szu.cz/program-skola-podporujici-zdravi OSHA (Occupational Safety and Health Administration European). (2010). Mainstreaming occupational safety and health into university education. https://osha.europa.eu/en/publications/ mainstreaming-occupational-safety-and-health-university-education OSHA (Occupational Safety and Health Administration). (2021). https://www.osha.gov/ Pokorná, M. (2009). Indikátory a kritéria. http://www.bezpecna-skola.cz/indikatory-a-kriteria Prokopová, A., \& Reissmannová, J. (2008). Učitelé a první pomoc - cesty ke kompetenci [Teachers and first aid - paths to competence]. Škola a zdraví, 21, 36, 34-85. 
Reissmannová, J. (2005). Zdravá škola: teorie a praxe (historie a současnost) [Healthy school: Theory and practice (history and present)]. Faculty of Education Masaryk University.

Reissmannová, J. (2010). Problematika první pomoci v kontextu rozvoje zdravotní gramotnosti ve školním prostředí [First aid issues in the context of health literacy development in the school environment]. https://is.muni.cz/th/pug2p/

Safe School. (2016). Bezpečná škola. http://www.bezpecna-skola.cz/Home SHE (Schools for Health in Europe). (2021). https://www.schoolsforhealth.org/ Slaná Reissmannová, J. (2021). Mezinárodní doporučení v oblasti ochrany veřejného zdraví a jejich implementace $v$ České republice s akcentem na oblast mimořádných událostí a krizových situací [International recommendations in the area of public health protection and their implementation in the Czech Republic with an emphasis on emergency and crisis situations]. Faculty of Medicine Palacký University Olomouc.

Svoboda, M., \& Gažáková, E. (2020). Osobnostně sociální rozvoj studentů - budoucích učitelů [Personal and social development of students - future teachers]. https://dspace5.zcu.cz/ bitstream/11025/37192/1/FINAL_Osobnostne_socialni_rozvoj_studentu_budoucich_ucitelu.pdf Svoboda, M. (2017). Psychosociální interakční výcvik v pedagogické praxi [Psychosocial interaction training in pedagogical practice]. Pedagogická fakulta Západočeské university Plzeň. The Ministry of Education, Youth and Sports of the Czech Republic. (2003). Pokyn MŠMT k začlenění tematiky ochrany člověka za mimořádných událostí do vzdělávacích programů a dodatek $k$ učebním dokumentưm pro základní školy, střední školy, speciální školy a vyšší odborné školy - ochrana člověka za mimořádných událostí [Instruction of the Ministry of Education, Youth and Sports to include the topic of human protection in emergencies in educational programmes and a supplement to teaching documents for primary schools, secondary schools, special schools and higher vocational schools - human protection in emergencies]. https://www.msmt.cz/ministerstvo/pokyn-msmtk-zacleneni-tematiky-ochrany-cloveka-za-mimoradnych-udalosti-do-vzdelavacich-programua-dodatek-k-ucebnim-dokumentum-pro-zakladni-skoly-stredni-skoly-specialni-skoly-a-vyssiodborne-skoly-ochrana-cloveka-za-mimoradnych-udalosti-1

The Ministry of Education, Youth and Sports of the Czech Republic. (2019). Konference Strategie vzdèlávací politiky ČR 2030+ (Revize rámcových vzdělávacích programů [Conference of the Education Policy Strategy of the Czech Republic 2030+ (Revision of the Framework Educational Programmes)]. https://www.youtube.com/watch?v=pHAg_LAMQoE

Tilcerová, E. (2010). Ochrana člověka za mimořádných událostí - nové trendy ve výuce

[Human protection in emergencies - new trends in teaching]. https://dk.upce.cz/ bitstream/handle/10195/37999/Tilcerov\%C3\%A1E_Ochrana\%C4\%8Clov\%C4\%9Bka_2010. pdf? sequence $=1$ \&isAllowed $=y$ 


\section{Biographical note}

Jitka Slaná Reissmannová, $\mathrm{PhD}$, is an assistant professor at the Department of Physical and Health Education at the Faculty of Education, Masaryk University in Brno. She specializes in health education issues at the 2nd stage of primary schools, especially in the area of prevention of chronic non-infectious diseases and old age syndrome, reproductive health, first aid and public health. Research is focused on curriculum of health education and didactic approaches to education of above mentioned topics. She is a member of the expert working group of the State Health Institute of the Health Promoting School program and is also a lecturer and advisor to the program. She is also Vice-President of the Association for Health Promotion and Health Education. She is an active lecturer at conferences in the Czech Republic. She is the author of more than a hundred professional articles, popularizing texts and teaching materials. 